\title{
Transcriptomic profiling of radiation-resistant or -sensitive human colorectal cancer cells: Acute effects of a single $\mathrm{X}$-radiation dose
}

\author{
CHENG E. NG ${ }^{1}$, QING Y. LIU ${ }^{2}$, SAMI S. QUTOB ${ }^{3}$, BRADLEY J. SCOTT ${ }^{1}$, WEI L. TAN ${ }^{1}$ and FELIX M. MESAK ${ }^{1}$ \\ ${ }^{1}$ Cancer Therapeutics, Ottawa Health Research Institute, 501 Smyth Road, Ottawa, Ontario K1H 8L6; ${ }^{2}$ Institute for \\ Biological Sciences, National Research Council of Canada, 1200 Montreal Rd., M-54, Ottawa, Ontario K1A 0R6; \\ ${ }^{3}$ Radiation Protection Bureau, Health Canada, 775 Brookfield Road, Ottawa, Ontario K1A 1C1, Canada
}

Received October 10, 2006; Accepted December 11, 2006

\begin{abstract}
We previously isolated several clones that were closely-related genetically from a human colorectal tumor (HCT116) cell line. These clones displayed significantly different X-radiation response phenotypes. In this paper, we investigated how a single dose of X-radiation modulated the transcriptomic profiles of either the radiation-resistant (HCT116 Clone2_XRR) or the radiation-sensitive (HCT116 ${ }^{\text {CloneK_XRS }}$ ) clone when each was compared to a reference clone, HCT116 Clone10_control. The latter represented a control clone that displayed a similar X-radiation response as the parental HCT116 cells. Pooled RNAs were obtained from HCT116 Clone2_XRR, HCT116 ${ }^{\text {CloneK_XRS }}$ or HCT116 Clone10_control cells either before or at $10 \mathrm{~min}, 6$ or $24 \mathrm{~h}$ after treatment with 4-Gy X-radiation. Transcriptomic profiles were assessed by cDNA microarrays. At least three independent experiments were carried out for each time point and statistical analysis was performed by paired t-test $(\mathrm{p}<0.05)$. From 19,200 genes/ ESTs examined, we identified only 120 genes/ESTs that were differentially expressed at any one of these four time points. Interestingly, different patterns of gene modulation were observed between the radiation-sensitive and radiationresistant clones. However, the fold changes of gene modulation were generally small (2-3 fold). Surprisingly, only $12.7 \%$ of 79 genes involved in DNA damage sensor/repair and cell cycle and between 2.6 and $9.2 \%$ of 76 genes involved in apoptosis, were significantly modulated in these early time points following irradiation. By comparison, up to $10 \%$ of 40 known housekeeping genes were differentially expressed. Thus in our experimental model, we were able to detect the
\end{abstract}

Correspondence to: Dr Cheng E. Ng, Cancer Therapeutics, Ottawa Health Research Institute, 501 Smyth Road, Ottawa, Ontario K1H 8L6, Canada

E-mail: cng@ohri.ca

Key words: cDNA microarray, colorectal tumor, HCT116, Xradiation, transcriptomic profiling up-regulation or down-regulation of mostly novel genes and/or pathways in the acute period (up to $24 \mathrm{~h}$ ) following a single dose of 4-Gy X-radiation.

\section{Introduction}

Radiotherapy remains a major modality for treating cancer and approximately half of all cancer patients currently receive radiation at some point during their treatment (1). Because of its potential clinical relevance, the biological basis for the expression of resistance, or conversely, sensitivity to $\mathrm{X}$-radiation (XR) has been actively investigated for several decades. Although it is now generally accepted that cellular responses to XR stress include sensing, signaling and repairing DNA damage $(2,3)$, both the genetic basis as well as the molecular mechanisms of cellular response to XR are generally still not well characterized.

More recent efforts to examine the genetic basis of cellular resistance or sensitivity to XR have employed high throughput, genome-wide screening using cDNA or oligonucleotide microarrays (4-8). However, except for Kitahara et al (6), the number of genes screened (e.g. 558 and 1176 genes) $(4,5,7)$ was usually too small to allow a meaningful global analysis of genetic response following XR. In addition, the well-documented heterogeneity often present in tumor cells/tissues in vivo is another factor that can affect the unequivocal identification of an XR-resistant or -sensitive genetic signature(s) from these studies.

In order to possibly address some of the previously stated deficiencies, we employed a cDNA microarray that contained a large number of genes/ESTs (i.e. 19,200, covering approximately one-third of all human genes). We compared the in vitro transcriptomic profiles of clones derived from a human colorectal tumor cell line that differed significantly in their XR-response phenotypes (9) following treatment with XR. We believe that such an approach would enhance the probability of deciphering the genetic signatures, if any, that were specifically associated with either XR-resistance or -sensitivity. This is because the genetic composition of our closely-related clones would be largely similar (or at least considerably less variable than that in genetically unrelated radiation-resistant or radiationsensitive cell lines). Our approach would be especially relevant 
if the differences in genetic expression between the radiationresistant and -sensitive cells involve only a relatively small number of genes that would otherwise be very difficult to identify from a background of high genetic variation (most of which are unrelated to the expression of the radiationresponse phenotypes).

Current knowledge suggests that activation and/or inhibition of several genes/pathways occur even in the acute (i.e. early) period following irradiation. The latter likely precedes the more apparent cellular effects (e.g. necrosis, apoptosis), associated with DNA damage, which are observed several hours or days later following XR (1). Therefore, in this study, we examined the global patterns of gene expression occurring up to $24 \mathrm{~h}$ following treatment with a single dose of $4 \mathrm{~Gy}$ XR in both the XR-resistant (HCT116 ${ }^{\text {Clone2_XRR }}$ ) or XR-sensitive (HCT116 ${ }^{\text {CloneK_XRS) }}$ cells for genetic signatures that could be potentially associated with the manifestation of subsequent XR-resistance or -sensitivity in these cells.

\section{Materials and methods}

Isolation of HCT116 clones with different XR response phenotypes. HCT $116^{\text {Clone2_XRR }}$, HCT $116^{\text {CloneK_XRS }}$ and HCT116 $6^{\text {Clone10_control }}$ were all isolated at the same time (9). HCT116 ${ }^{\text {Clone2_XRR }}$ and HCT116 $6^{\text {CloneK_XRS }}$ were subsequently characterized as an XR-resistant and XR-sensitive clone (relative to the parental HCT116 cell line), respectively. By contrast, HCT116 Clone10_control displayed a similar XRresponse phenotype as the parental HCT116 cells (9). HCT116 Clone10_control was, therefore, used as the reference (control) cell line for our microarray analysis.

$X R$ treatment. Cells were seeded into a $25-\mathrm{cm}^{2}$ flask on day 0 and used for experimentation on day 3 such that, at the time of irradiation, they were in the exponential phase of growth (9). We carefully controlled growth conditions (temperature, $\mathrm{pH}$, nutrient availability) to minimize variations in genetic expression that were unrelated to treatment effects. Cells were treated with a single dose of $4 \mathrm{~Gy}$ of XR at room temperature and returned to the incubator at $37^{\circ} \mathrm{C}$ until they were harvested for RNA extraction. A 250-kVp X-ray unit (Pantak, CT, USA) was used at a dose-rate of $150 \mathrm{cGy} / \mathrm{min}$. RNA was collected for DNA microarray analysis either before or at $10 \mathrm{~min}, 6 \mathrm{~h}$ or $24 \mathrm{~h}$ following the 4-Gy dose.

\section{cDNA microarray}

First-strand cDNA synthesis, labeling, and hybridization. To cover a significant number of genes that are expressed by human cells, we used a commercial human 19,200 cDNA microarray from the University Health Network, Ontario Cancer Institute, Toronto, Canada (http://www.microarray.ca). The microarray slides consisted of spotted PCR amplified ESTs representing both known and unknown genes. We employed dual channel microarray analysis, which involved conjugating two different fluorescent dyes, namely Cyanine-3 (Cy3) and Cyanine-5 (Cy5), to the first-strand cDNA of either the reference (HCT116 Clone10_control) or treated (HCT116 $6^{\text {Clone2_XRR }}$ or HCT116 ${ }^{\text {CloneK_XRS }}$ ) cells. Thus the genomic profiles of the two clones of interest (radioresistant HCT116 Clone2_XRR or radiosensitive HCT116 $6^{\text {CloneK_XRS }}$ ) were individually compared against the reference clone (HCT116 ${ }^{\text {Clone10_control) }}$ to evaluate any differences in genetic expression after irradiation.

To create the first cDNA strand, we used RNA that was pooled from at least three different batches of cells. We used indirect labeling with the fluorochromes. Hybridization of labeled cDNA for each time point was repeated three or four times with dye swaps on one of them. Overall, we have followed the Minimum Information About a Microarray Experiment (MIAME) protocol (10) that has been developed by the Microarray Gene Expression Data society [http://www. mged.org/miame].

Data acquisition and processing. Slides were scanned using a ScanArray 5000 confocal scanner (Packard BioScience, Meriden CT, USA) with excitation/emission wavelengths of $543 / 570 \mathrm{~nm}$ for Cy3 or $633 / 670 \mathrm{~nm}$ for Cy5, at $10-\mu \mathrm{m}$ resolution. Image files were quantified with QuantArray v3.0 (Packard BioScience) using an adaptive spot finding method to generate spot intensities from mean pixel values. Poor quality spots were flagged manually by the user and recorded in the output file to be used as an 'ignore spot' filter. The tab delimited text data files produced were subsequently preprocessed using macros in Microsoft Excel 2000 (Microsoft Corporation, Redmond, WA).

Each data file contained intensity data for 19200 features measured in two channels, $\mathrm{Ch} 1$ and $\mathrm{Ch} 2$. Ch1 data represented intensity measurements from the control (HCT116 Clone10_control) sample and $\mathrm{Ch} 2$ data represented intensity measurements from the experimental (either HCT116 Clone2_XRR or HCT116 CloneK_XRS) sample. Median subarray background values were calculated for each channel and subtracted from the respective intensity values. Spots flagged by the user during quantification (the 'ignore' filter) and spots failing to meet the following criteria: intensity $>2.5$-fold background and intensity $>5$ th- and $<98$ thpercentile of all intensities for each channel, were filtered out and not used in the computation of normalization correction factors. Corrected intensity data were expressed as logarithmic values (base 2) and corrected for dye bias (normalised) using a linear-regression correction applied to the $\mathrm{Ch} 2$ intensities for all the spots in each subarray. This correction yielded a Ch2 versus Ch1 scatter plot with a linear regression best-fit line having slope 1 and intercept $0 . \log _{2}$ ratios representing expression values for experimental (HCT116 $6^{\text {Clone2_XRR }}$ or HCT116 CloneK_XRS) versus control (HCT116 ${ }^{\text {Clone10_control) }}$ samples were then calculated and data was analysed in Excel to select for spots with a mean $\log _{2}$ ratio of $\geq 0.9$ for which all three or four replicates were present.

Statistical testing. cDNA microarray analysis was performed at least in triplicate for each time point (unirradiated, $10 \mathrm{~min}$, $6 \mathrm{~h}$, and $24 \mathrm{~h}$ after XR). We evaluated the means of the normalized data representing the differential genetic expression between unirradiated or irradiated HCT116 ${ }^{\text {Clone2_XRR }}$ or HCT116 CloneK_XRS versus unirradiated HCT116 $6^{\text {Clone10_control }}$. We used the paired t-test to determine genes that were statistically different from each other at $\mathrm{p}<0.05$. Cluster analysis was performed using Genesis (11).

Data deposition. All microarray data have been deposited at the Gene Expression Omnibus (GEO) database [www. 
Table I. Genes/ESTs differentially modulated following 4-Gy X-radiation.

\begin{tabular}{|c|c|c|c|c|c|c|c|c|c|c|}
\hline Gene (acc. no.) & $\mathrm{nX}$ & XKM10 & ХKH6 & XKH24 & $\mathrm{nX}$ & $\mathrm{X} 2 \mathrm{M} 10$ & $\mathrm{X} 2 \mathrm{H} 6$ & $\mathrm{X} 2 \mathrm{H} 24$ & CLK & CL2 \\
\hline syndecan 4, SDC4 (AA002237) & 0 & -0.767807 & -0.393392 & -0.363648 & 0 & $\underline{-2.25621}$ & -0.77154 & 0.0582158 & $\mathrm{X}$ & $\mathrm{D}$ \\
\hline unknown EST (AA011705) & 0 & 0.3544456 & -0.134959 & 0.376913 & 0 & -0.83271 & $\underline{-0.96192}$ & 0.2537013 & $\mathrm{X}$ & $\mathrm{D}$ \\
\hline $\begin{array}{l}\text { aldehyde dehydrogenase } 2, \\
\text { ALDH2 (AA012947) }\end{array}$ & 0 & $\underline{-2.199248}$ & -1.587954 & $\underline{-1.753873}$ & 0 & 0.1210285 & 0.14375 & -0.305618 & $\mathrm{D}$ & $\mathrm{X}$ \\
\hline $\begin{array}{l}\text { forkhead box O1A, } \\
\text { FOXO1A (AA019811) }\end{array}$ & 0 & $\underline{-1.632036}$ & $\underline{-1.558346}$ & -1.248878 & 0 & -0.216105 & $\underline{1.05264}$ & -0.101708 & $\mathrm{D}$ & $\mathrm{U}$ \\
\hline unknown EST (AA026575) & 0 & $\underline{-1.464402}$ & $\underline{-1.304732}$ & $\underline{-1.413943}$ & 0 & -0.109877 & -0.0127 & 0.2948874 & $\mathrm{D}$ & $\mathrm{X}$ \\
\hline unknown EST (AA028183) & 0 & 0.2739923 & 0.2239 & 0.08387 & 0 & 0.2520984 & $\underline{-1.73649}$ & $\underline{-0.934603}$ & $\mathrm{X}$ & $\mathrm{D}$ \\
\hline unknown EST (AA033551) & 0 & -0.055906 & 0.701023 & -0.11117 & 0 & $\underline{-1.617145}$ & $\underline{1.47418}$ & $\underline{0.9543719}$ & $\mathrm{X}$ & $\mathrm{C}$ \\
\hline unknown EST (AA036730) & 0 & -0.008625 & -0.752101 & 0.251441 & 0 & -0.064187 & 0.66998 & 0.140714 & $\mathrm{X}$ & $\mathrm{X}$ \\
\hline $\begin{array}{l}\text { quinoid dihydropteridine reductase, } \\
\text { QDPR (AA057300) }\end{array}$ & 0 & 0.0091171 & -0.05899 & 0.090017 & 0 & $\underline{1.5919182}$ & 0.3923 & 0.5798255 & $X$ & $\mathrm{U}$ \\
\hline unknown EST (AA057352) & 0 & 0.7617934 & 0.250062 & 0.015144 & 0 & -0.641988 & -0.11916 & 0.3289699 & $\mathrm{X}$ & $\mathrm{X}$ \\
\hline $\begin{array}{l}\text { amiloride binding protein } 1, \\
\text { ABP1 (AA088634) }\end{array}$ & 0 & -0.803722 & $\underline{-0.934804}$ & -0.88644 & 0 & $\underline{1.2631889}$ & 0.48707 & 0.4194689 & $\mathrm{D}$ & $\mathrm{U}$ \\
\hline $\begin{array}{l}\text { SnRNP assembly defective } 1, \\
\text { SAD1 (AA130140) }\end{array}$ & 0 & -0.085008 & 0.102123 & $\underline{-0.925053}$ & 0 & 0.0637079 & -0.00366 & 0.1600033 & $\mathrm{D}$ & $\mathrm{X}$ \\
\hline unknown EST (AA131587) & 0 & -0.483462 & -0.357118 & -0.494603 & 0 & -0.269116 & $\underline{1.43066}$ & -0.06019 & $\mathrm{X}$ & $\mathrm{U}$ \\
\hline $\begin{array}{l}\text { hypothetical protein FLJ32949 } \\
\text { (AA134695) }\end{array}$ & 0 & -0.574245 & -0.727608 & -0.55289 & 0 & -1.679871 & $\underline{-1.06918}$ & 0.0596163 & $X$ & $\mathrm{D}$ \\
\hline $\begin{array}{l}\text { docking protein } 1, \text { DOK } 1 \\
\text { (AA142943) }\end{array}$ & 0 & $\underline{1.2376327}$ & $\underline{1.288834}$ & 1.645372 & 0 & 0.0465459 & -0.02784 & -0.107141 & $\mathrm{U}$ & $\mathrm{X}$ \\
\hline unknown EST (AA195650) & 0 & -1.197727 & $\underline{-1.193106}$ & -1.557824 & 0 & 0.605065 & $\underline{1.48261}$ & 0.6305092 & $\mathrm{D}$ & $\mathrm{U}$ \\
\hline unknown EST (AA203190) & 0 & $\underline{-2.244622}$ & $\underline{-1.123994}$ & -0.885398 & 0 & -1.664681 & 0.02939 & 0.6731688 & $\mathrm{D}$ & $\mathrm{D}$ \\
\hline $\begin{array}{l}\text { hypothetical protein C330039G02 } \\
\text { (AA203210) }\end{array}$ & 0 & -0.195492 & -0.284402 & 0.017179 & 0 & 0.29297 & 1.56364 & 0.1932113 & $\mathrm{X}$ & $\mathrm{U}$ \\
\hline unkown EST (AA203372) & 0 & 0.2824976 & -0.458571 & -0.37653 & 0 & -0.162058 & 0.19796 & $\underline{0.934972}$ & $\mathrm{X}$ & $\mathrm{U}$ \\
\hline unknown EST (AI733545) & 0 & -0.115112 & -0.406787 & -0.476558 & 0 & $\underline{-1.08759}$ & $\underline{-1.83287}$ & -0.449929 & $X$ & $\mathrm{D}$ \\
\hline $\begin{array}{l}\text { cytochrome c oxidase I, } \\
\text { MTCO1 (BE879779) }\end{array}$ & 0 & 0.2081552 & 0.157589 & 0.057115 & 0 & 0.1878588 & -0.01529 & $\underline{1.5396826}$ & $X$ & $\mathrm{U}$ \\
\hline $\begin{array}{l}\text { hypothetical protein FLJ12892 } \\
\text { (BG323782) }\end{array}$ & 0 & -0.09569 & 0.354808 & -0.31889 & 0 & -0.563104 & -0.08038 & $\underline{0.970921}$ & $X$ & $\mathrm{U}$ \\
\hline unknown EST (BG484850) & 0 & 0.3271846 & 0.734569 & -0.028727 & 0 & -0.065012 & 0.20306 & $\underline{1.224932}$ & $X$ & $\mathrm{U}$ \\
\hline unknown EST (BG686771) & 0 & 0.2048411 & $\underline{1.0553}$ & -0.499527 & 0 & $\underline{-1.134306}$ & -0.61205 & 0.4218103 & $\mathrm{U}$ & $\mathrm{D}$ \\
\hline $\begin{array}{l}\text { hypothetical protein FLJ30747 } \\
\text { (BM480413) }\end{array}$ & 0 & -0.317358 & -0.175733 & -0.091828 & 0 & $\underline{-1.431875}$ & 0.69078 & -0.017616 & $X$ & $\mathrm{D}$ \\
\hline unknown EST (BM543848) & 0 & -0.495782 & -0.073183 & 0.187068 & 0 & -1.190563 & -0.14053 & -1.150808 & $\mathrm{X}$ & $\mathrm{D}$ \\
\hline unknown EST (BM743125) & 0 & -0.42756 & -0.153136 & -0.363833 & 0 & -0.061753 & 0.6295 & $\underline{1.3715098}$ & $\mathrm{X}$ & $\mathrm{U}$ \\
\hline $\begin{array}{l}\text { hypothetical protein LOC51315 } \\
\text { (BM789783) }\end{array}$ & 0 & -0.222416 & -0.217 & -0.600764 & 0 & 0.5354075 & $\underline{1.50174}$ & 0.2442739 & $X$ & $\mathrm{U}$ \\
\hline $\begin{array}{l}\text { guanine nucleotide binding protein, } \\
\text { GNG12 (BQ006745) }\end{array}$ & 0 & 0.2993403 & 0.481032 & 0.223196 & 0 & -0.273616 & 0.05404 & $\underline{1.3401549}$ & $X$ & $\mathrm{U}$ \\
\hline unknown EST (H03162) & 0 & 0.2745444 & 0.03916 & 0.333894 & 0 & -0.156248 & -0.70161 & 0.5441005 & $X$ & $X$ \\
\hline unknown EST (H03241) & 0 & 0.1324497 & -1.278608 & 0.43299 & 0 & -0.626798 & 0.62678 & 0.1750505 & $\mathrm{D}$ & $\mathrm{X}$ \\
\hline
\end{tabular}


Table I. Continued.

\begin{tabular}{|c|c|c|c|c|c|c|c|c|c|c|}
\hline Gene (acc. no.) & $\mathrm{nX}$ & XKM10 & ХKH6 & XKH24 & $\mathrm{nX}$ & X2M10 & $\mathrm{X} 2 \mathrm{H} 6$ & $\mathrm{X} 2 \mathrm{H} 24$ & CLK & CL2 \\
\hline unknown EST (H05626) & 0 & -0.816921 & $\underline{-1.071031}$ & $\underline{-1.399326}$ & 0 & -0.030707 & -0.44654 & -0.0903 & $\mathrm{D}$ & $\mathrm{X}$ \\
\hline $\begin{array}{l}\text { hypothetical protein FLJ13646 } \\
\text { (H08212) }\end{array}$ & 0 & $\underline{-1.067628}$ & $\underline{-1.215757}$ & $\underline{-1.556215}$ & 0 & 0.1369023 & 0.41129 & 0.270286 & $\mathrm{D}$ & $\mathrm{X}$ \\
\hline unknown EST (H11978) & 0 & 0.6221658 & $\underline{1.27417}$ & $\underline{1.618968}$ & 0 & 0.0417325 & -0.52051 & -0.311389 & $\mathrm{U}$ & $\mathrm{X}$ \\
\hline unknown EST (H12056) & 0 & 0.0049069 & 0.061363 & -0.09233 & 0 & 0.2062596 & -0.04744 & $\underline{0.9080547}$ & $\mathrm{X}$ & $\mathrm{U}$ \\
\hline unknown EST (H15113) & 0 & -0.555975 & -1.124034 & -0.465426 & 0 & -0.20126 & 0.31887 & 0.146012 & $\mathrm{D}$ & $\mathrm{X}$ \\
\hline unknown EST (H15461) & 0 & -1.550598 & $\underline{-1.765666}$ & $\underline{-1.659774}$ & 0 & -0.300321 & 0.07184 & -0.201811 & $\mathrm{D}$ & $\mathrm{X}$ \\
\hline dishevelled 3, DVL3 (H15755) & 0 & 0.0065637 & $\underline{-1.03209}$ & -0.205351 & 0 & 0.3270366 & 0.70435 & 0.2740811 & $\mathrm{D}$ & $\mathrm{X}$ \\
\hline unknown EST (H16554) & 0 & $\underline{-1.650642}$ & $\underline{-1.899144}$ & $\underline{-1.57563}$ & 0 & -0.276241 & -0.15996 & 0.3325391 & $\mathrm{D}$ & $\mathrm{X}$ \\
\hline unknown EST (H16638) & 0 & -0.240894 & -0.285039 & -0.158298 & 0 & -0.100469 & -0.75403 & 0.4344342 & $\mathrm{X}$ & $\mathrm{X}$ \\
\hline unknown EST (H16843) & 0 & 0.2039155 & 0.060046 & 0.351377 & 0 & $\underline{-1.63668}$ & -1.22369 & -1.239181 & $\mathrm{X}$ & $\mathrm{D}$ \\
\hline $\begin{array}{l}\text { orthodenticle homolog } 2 \text {, } \\
\text { OTX2 (H17804) }\end{array}$ & 0 & $\underline{1.1238202}$ & -0.151012 & $\underline{1.381081}$ & 0 & 0.0727199 & -0.13052 & $\underline{1.1886466}$ & $\mathrm{U}$ & $\mathrm{U}$ \\
\hline $\begin{array}{l}\text { ribosomal pseudouridine synthase C, } \\
\text { RLUCL (H18934) }\end{array}$ & 0 & 0.8451949 & 0.691694 & $\underline{1.473313}$ & 0 & 0.2419193 & 0.09515 & 0.5660278 & $\mathrm{U}$ & $\mathrm{X}$ \\
\hline $\begin{array}{l}\text { ELKL motif kinase, EMK1 } \\
(\mathrm{H} 19443)\end{array}$ & 0 & 0.7934429 & 0.885895 & 0.603261 & 0 & -0.10041 & -0.89915 & 0.3016943 & $\mathrm{X}$ & $\mathrm{X}$ \\
\hline unknown EST (H23469) & 0 & $\underline{1.6194951}$ & $\underline{1.12569}$ & 1.487276 & 0 & 0.2880296 & 0.28593 & 0.196801 & $\mathrm{U}$ & $\mathrm{X}$ \\
\hline $\begin{array}{l}\text { zinc finger protein } 35, \mathrm{ZNF} 35 \\
(\mathrm{H} 27140)\end{array}$ & 0 & 0.0191513 & 0.646686 & -0.001834 & 0 & $\underline{1.093205}$ & $\underline{2.32635}$ & 0.2601322 & $\mathrm{X}$ & $\mathrm{U}$ \\
\hline unknown EST (H28583) & 0 & 1.2803048 & 1.218945 & 1.228101 & 0 & 0.2283784 & 0.6 & 55 & $\mathrm{U}$ & $\mathrm{X}$ \\
\hline $\begin{array}{l}\text { adipose specific 2, APM2 } \\
\text { (H43908) }\end{array}$ & 0 & $\underline{1.0741408}$ & $\underline{1.103721}$ & 1.368497 & 0 & -0.598838 & 266 & -0.107208 & $\mathrm{U}$ & $\mathrm{X}$ \\
\hline unknown EST (H44869) & 0 & $\underline{-1.56441}$ & $\underline{-1.295673}$ & $\underline{-1.420006}$ & 0 & -0.234266 & 0.58951 & -0.465082 & $\mathrm{D}$ & $\mathrm{X}$ \\
\hline unknown EST (H50037) & 0 & -0.810739 & $\underline{-1.565103}$ & -0.622605 & 0 & -0.028379 & $\underline{-1.97234}$ & $\underline{1.1068237}$ & $\mathrm{D}$ & $\mathrm{C}$ \\
\hline unknown EST (H55855) & 0 & 0.1439001 & 0.369702 & 0.621326 & 0 & $\underline{-1.715217}$ & $\underline{-1.31917}$ & -0.279797 & $\mathrm{X}$ & $\mathrm{D}$ \\
\hline $\begin{array}{l}\text { aryl hydrocarbon receptor, } \\
\text { AHR (H64609) }\end{array}$ & 0 & 0.0880276 & 0.355546 & 0.168607 & 0 & -0.008717 & 0.21063 & $\underline{-1.009466}$ & $\mathrm{X}$ & $\mathrm{D}$ \\
\hline $\begin{array}{l}\text { tumor rejection antigen } 1 \text {, TRA1 } \\
\text { (H65057) }\end{array}$ & 0 & $\underline{1.6617911}$ & $\underline{1.66679}$ & $\underline{1.759861}$ & 0 & -0.189089 & -0.42816 & -0.084183 & $\mathrm{U}$ & $\mathrm{X}$ \\
\hline unknown EST (H66628) & 0 & -0.820622 & -0.446668 & 0.299959 & 0 & -0.056598 & $\underline{1.32828}$ & $\underline{1.1336859}$ & $\mathrm{X}$ & $\mathrm{U}$ \\
\hline unknown EST (H77862) & 0 & 0.5719748 & 0.310016 & 0.138799 & 0 & $\underline{-0.967303}$ & 0.39992 & 0.4265029 & $\mathrm{X}$ & $\mathrm{D}$ \\
\hline unknown EST (H82080) & 0 & -0.173898 & -0.429105 & -0.366771 & 0 & -0.234047 & 0.22085 & 0.0198296 & $\mathrm{X}$ & $\mathrm{X}$ \\
\hline unknown EST (H86277) & 0 & $\underline{-1.577841}$ & $\underline{-1.645488}$ & $\underline{-1.450416}$ & 0 & -0.109486 & 0.07699 & $\underline{1.009593}$ & $\mathrm{D}$ & $\mathrm{U}$ \\
\hline $\begin{array}{l}\text { carboxypeptidase A6, CPA6 } \\
(\mathrm{H} 86718)\end{array}$ & 0 & -0.229556 & -1.03253 & -0.049509 & 0 & -0.702382 & 0.34976 & 0.0057267 & $\mathrm{D}$ & $X$ \\
\hline unknown EST (H91799) & 0 & $\underline{-1.103281}$ & $\underline{-1.278296}$ & $\underline{-1.967551}$ & 0 & -0.469133 & 0.28705 & -0.007038 & $\mathrm{D}$ & $\mathrm{X}$ \\
\hline $\begin{array}{l}\text { HIV enhancer-binding protein } 1 \text {, } \\
\text { (HIVEP1 (N28795) }\end{array}$ & 0 & -0.142573 & -0.554002 & 0.235003 & 0 & -1.30088 & 0.16853 & 0.0418772 & $\mathrm{X}$ & D \\
\hline unknown EST (N31073) & 0 & -0.106794 & -0.23665 & 0.122625 & 0 & -0.589285 & -0.30456 & -0.675458 & $\mathrm{X}$ & $\mathrm{X}$ \\
\hline unknown EST (N42890) & 0 & $\underline{-1.563697}$ & $\underline{-1.523074}$ & $\underline{-1.730551}$ & 0 & 0.325438 & -0.10325 & $\underline{1.0929614}$ & $\mathrm{D}$ & $\mathrm{U}$ \\
\hline unknown EST (N43838) & 0 & -0.642559 & -0.614562 & -0.436279 & 0 & $\underline{0.9870005}$ & $\underline{1.40439}$ & $\underline{1.6404498}$ & $\mathrm{X}$ & $\mathrm{U}$ \\
\hline $\begin{array}{l}\text { hypothetical protein FLJ } 20373 \\
\text { (N43949) }\end{array}$ & 0 & 0.1855426 & 0.136913 & 0.133667 & 0 & $\underline{1.2510661}$ & 0.17383 & 0.4125498 & $X$ & $\mathrm{U}$ \\
\hline
\end{tabular}


Table I. Continued.

\begin{tabular}{|c|c|c|c|c|c|c|c|c|c|c|}
\hline Gene (acc. no.) & $\mathrm{nX}$ & XKM10 & XKH6 & XKH24 & $\mathrm{nX}$ & $\mathrm{X} 2 \mathrm{M} 10$ & $\mathrm{X} 2 \mathrm{H} 6$ & $\mathrm{X} 2 \mathrm{H} 24$ & CLK & CL2 \\
\hline unknown EST (N45592) & 0 & $\underline{1.3154101}$ & $\underline{1.201103}$ & $\underline{1.000211}$ & 0 & -0.501734 & 0.22615 & -0.236035 & $\mathrm{U}$ & $\mathrm{X}$ \\
\hline unknown EST (N46185) & 0 & -0.294396 & 0.05117 & -0.010813 & 0 & $\underline{-0.955615}$ & $\underline{-0.03876}$ & 0.3633698 & $\mathrm{X}$ & $\mathrm{D}$ \\
\hline unknown EST (N76305) & 0 & -0.183563 & -0.246721 & -0.160114 & 0 & 0.121144 & $\underline{1.49191}$ & -0.157983 & $\mathrm{X}$ & $\mathrm{U}$ \\
\hline $\begin{array}{l}\text { anaphase-promoting complex } \\
\text { subunit 7, APC7 (N77334) }\end{array}$ & 0 & -0.295896 & -0.035985 & -0.20233 & 0 & $\underline{-1.127359}$ & -0.36623 & -0.235944 & $\mathrm{X}$ & $\mathrm{D}$ \\
\hline unknown EST (N99429) & 0 & -0.065583 & 0.29544 & -0.055477 & 0 & -0.311044 & 0.68763 & -0.864377 & $\mathrm{X}$ & $\mathrm{X}$ \\
\hline $\begin{array}{l}\text { peroxisomal membrane protein, } \\
\text { PMP34 (R00798) }\end{array}$ & 0 & 0.110734 & 0.586484 & 0.29577 & 0 & -0.359153 & -0.37391 & -1.545504 & $\mathrm{X}$ & $\mathrm{D}$ \\
\hline $\begin{array}{l}\text { heat shock } 70 \mathrm{kD} \text { protein } 2 \text {, HSPA } 2 \\
\text { (R12701) }\end{array}$ & 0 & 0.3654131 & $\underline{1.074449}$ & 0.292107 & 0 & 0.6382442 & 0.28019 & -0.121151 & $\mathrm{U}$ & $\mathrm{X}$ \\
\hline unknown EST (R13792) & 0 & 0.2189731 & 0.095252 & 0.379477 & 0 & 0.2121097 & -0.39043 & $\underline{0.9216404}$ & $X$ & $\mathrm{U}$ \\
\hline $\begin{array}{l}\text { hypothetical protein FLJ13677 } \\
\text { (R14890) }\end{array}$ & 0 & -1.223508 & -1.462333 & -1.42729 & 0 & 0.4303148 & 0.73268 & -0.476505 & $\mathrm{D}$ & $\mathrm{X}$ \\
\hline unknown EST (R15156) & 0 & -1.450293 & -1.563824 & -1.592532 & 0 & -0.629755 & $\underline{1.03935}$ & -0.622956 & $\mathrm{D}$ & $\mathrm{U}$ \\
\hline $\begin{array}{l}\text { constitutive photomorphogenic } 5 \text {, } \\
\text { COPS5 (R17665) }\end{array}$ & 0 & $\underline{1.6930348}$ & $\underline{1.8431}$ & $\underline{1.374234}$ & 0 & 0.0507865 & 0.57501 & 0.0777056 & $\mathrm{U}$ & $\mathrm{X}$ \\
\hline $\begin{array}{l}\text { adenosine monophosphate } \\
\text { deaminase 2, AMPD2 (R18428) }\end{array}$ & 0 & -0.558966 & -0.742981 & $\underline{-1.517481}$ & 0 & 0.0339866 & -0.0348 & -0.00216 & $\mathrm{D}$ & $X$ \\
\hline $\begin{array}{l}\text { hypothetical protein KIAA1337 } \\
\text { (R19342) }\end{array}$ & 0 & 0.1273212 & -0.818539 & 0.031022 & 0 & -0.285104 & $\underline{0.97644}$ & -0.33489 & $X$ & $\mathrm{U}$ \\
\hline unknown EST (R21903) & 0 & 0.6159576 & -0.229963 & -0.011248 & 0 & 0.3799189 & 0.38487 & 0.3619407 & $\mathrm{X}$ & $\mathrm{X}$ \\
\hline unknown EST (R32169) & 0 & $\underline{-1.129294}$ & $\underline{-1.631547}$ & -0.796432 & 0 & 0.217399 & 0.75814 & $\underline{1.0084654}$ & $\mathrm{D}$ & $\mathrm{U}$ \\
\hline $\begin{array}{l}\text { hypothetical protein KIAA0336 } \\
\text { (R34353) }\end{array}$ & 0 & $\underline{0.9489313}$ & 0.153417 & 0.678688 & 0 & -0.518663 & 0.11632 & -0.032765 & $\mathrm{U}$ & $\mathrm{X}$ \\
\hline unknown EST (R36956) & 0 & 0.3500348 & 0.432513 & -0.13583 & 0 & 0.6660148 & 0.13587 & $\underline{1.5380532}$ & $\mathrm{X}$ & $\mathrm{U}$ \\
\hline unknown EST (R39108) & 0 & -1.376124 & -1.583894 & -1.466098 & 0 & -0.592883 & -0.36378 & -0.282614 & $\mathrm{D}$ & $\mathrm{X}$ \\
\hline $\begin{array}{l}\text { hypothetical protein FLJ } 12270 \\
\text { (R40415) }\end{array}$ & 0 & $\underline{-1.304566}$ & -1.100582 & -0.6613 & 0 & -0.048576 & 0.08984 & 0.1467817 & $\mathrm{D}$ & $\mathrm{X}$ \\
\hline $\begin{array}{l}\text { hypothetical protein KIAA1474 } \\
\text { (R47756) }\end{array}$ & 0 & 0.7770195 & 0.068061 & -0.690684 & 0 & -0.093744 & $\underline{1.00537}$ & -0.031888 & $X$ & $\mathrm{U}$ \\
\hline hypothetical protein MGC11349 & 0 & $\underline{-1.920922}$ & $\underline{-1.780425}$ & $\underline{-1.794634}$ & 0 & 0.1591967 & 0.63697 & 0.4387162 & $\mathrm{D}$ & $X$ \\
\hline $\begin{array}{l}\text { unknown EST (R59057) } \\
\text { (R51714) }\end{array}$ & 0 & -0.427995 & -0.201702 & -0.544682 & 0 & 0.0989626 & $\underline{-1.31165}$ & -0.101213 & $\mathrm{X}$ & $\mathrm{D}$ \\
\hline $\begin{array}{l}\text { nuclear receptor interacting protein } 1 \text {, } \\
\text { NRIP1 (R59543) }\end{array}$ & 0 & -1.495714 & -1.001771 & $\underline{-1.414875}$ & 0 & -0.279866 & 0.30165 & $\underline{1.9059761}$ & $\mathrm{D}$ & $\mathrm{U}$ \\
\hline unknown EST (R59686) & 0 & 0.364622 & -0.790888 & 0.160418 & 0 & -0.056122 & -0.30384 & $\underline{1.5050521}$ & $\mathrm{X}$ & $\mathrm{U}$ \\
\hline unknown EST (R60381) & 0 & 0.3934539 & -0.393928 & 0.55526 & 0 & 0.6199335 & -0.86523 & 0.234403 & $\mathrm{X}$ & $\mathrm{X}$ \\
\hline $\begin{array}{l}\text { hypothetical protein MGC13523 } \\
\text { (R60408) }\end{array}$ & 0 & 0.4522971 & 0.256132 & 0.665815 & 0 & 0.269448 & $\underline{-0.99949}$ & 0.4546744 & $X$ & $\mathrm{D}$ \\
\hline unknown EST (R66260) & 0 & 0.1753452 & -0.355847 & 0.171716 & 0 & 0.3442395 & -0.36538 & 0.2967596 & $\mathrm{X}$ & $\mathrm{X}$ \\
\hline unknown EST (R73811) & 0 & -0.970637 & -0.426396 & -0.378095 & 0 & 0.3567765 & $\underline{1.42161}$ & 0.8114181 & $\mathrm{D}$ & $\mathrm{U}$ \\
\hline unknown EST (R83380) & 0 & $\underline{-1.082505}$ & $\underline{-1.463586}$ & $\underline{-1.313038}$ & 0 & -0.148791 & 0.12089 & -0.088558 & $\mathrm{D}$ & $\mathrm{X}$ \\
\hline growth arrest-specific 7, GAS7 & 0 & -0.106294 & -0.11778 & -0.015967 & 0 & $\underline{-0.95925}$ & -0.41366 & 0.1428517 & $\mathrm{X}$ & $\mathrm{D}$ \\
\hline
\end{tabular}
(R87411) 
Table I. Continued.

\begin{tabular}{|c|c|c|c|c|c|c|c|c|c|c|}
\hline Gene (acc. no.) & $\mathrm{nX}$ & XKM10 & XKH6 & XKH24 & $\mathrm{nX}$ & X2M10 & $\mathrm{X} 2 \mathrm{H} 6$ & $\mathrm{X} 2 \mathrm{H} 24$ & CLK & CL2 \\
\hline unknown EST (R95866) & 0 & 0.2583817 & -0.212536 & 0.004831 & 0 & -0.108863 & 0.3023 & $\underline{0.9875467}$ & $\mathrm{X}$ & $\mathrm{U}$ \\
\hline unknown EST (R96130) & 0 & -0.072768 & -0.156393 & -0.724068 & 0 & $\underline{0.9048777}$ & -0.83908 & 0.435283 & $\mathrm{X}$ & $\mathrm{U}$ \\
\hline unknown EST (R97278) & 0 & 0.3838929 & -0.289238 & -0.256295 & 0 & -0.129033 & 0.75986 & 0.8337395 & $\mathrm{X}$ & $\mathrm{X}$ \\
\hline unknown EST (T65632) & 0 & 1.2553302 & 0.741137 & $\underline{1.031973}$ & 0 & -0.286073 & -0.02255 & 0.0982468 & $\mathrm{U}$ & $\mathrm{X}$ \\
\hline $\begin{array}{l}\text { interleukin } 22 \text { receptor, IL22R } \\
\text { (T70354) }\end{array}$ & 0 & -0.58139 & $\underline{-1.33417}$ & -0.26222 & 0 & -0.342981 & 0.02007 & -0.277351 & $\mathrm{D}$ & $\mathrm{X}$ \\
\hline $\begin{array}{l}\text { hypothetical protein MGC43399 } \\
\text { (T78497) }\end{array}$ & 0 & 0.2841817 & 0.145744 & 0.535897 & 0 & $\underline{-1.605265}$ & $\underline{-1.51696}$ & $\underline{-1.202656}$ & $\mathrm{X}$ & $\mathrm{D}$ \\
\hline unknown EST (T80713) & 0 & 0.1678573 & -0.188489 & -0.41272 & 0 & 0.513166 & 1.78758 & 1.130611 & $\mathrm{X}$ & $\mathrm{U}$ \\
\hline unknown EST (T83194) & 0 & -0.364471 & $\underline{-1.188879}$ & -0.782477 & 0 & 0.0996041 & $\underline{-0.91976}$ & 0.1030542 & $\mathrm{D}$ & $\mathrm{D}$ \\
\hline unknown EST (T84981) & 0 & 0.1450516 & 0.369527 & -0.000778 & 0 & 0.2973081 & $\underline{-0.95459}$ & -0.25447 & $\mathrm{X}$ & $\mathrm{D}$ \\
\hline unknown EST (T87942) & 0 & 0.2160745 & 0.018646 & -0.410066 & 0 & $\underline{-2.142805}$ & $\underline{0.98627}$ & -0.134199 & $\mathrm{X}$ & $\mathrm{C}$ \\
\hline unknown EST (T94384) & 0 & -1.550362 & $\underline{-1.493363}$ & $\underline{-1.357176}$ & 0 & -0.408555 & 0.16983 & -0.056631 & $\mathrm{D}$ & $\mathrm{X}$ \\
\hline $\begin{array}{l}\text { hypothetical protein LOC145622, } \\
\text { SNURF-SNRPN (T95551) }\end{array}$ & 0 & 0.4617116 & -0.0291 & 0.708126 & 0 & 0.0357012 & -0.86984 & 1.2552385 & $\mathrm{X}$ & $\mathrm{U}$ \\
\hline $\begin{array}{l}\text { hypothetical protein ORF4, } \\
\text { LOC56834 (T95699) }\end{array}$ & 0 & 0.5906601 & -0.086866 & 0.220541 & 0 & $\underline{0.9405153}$ & 0.55052 & 0.3471452 & $X$ & $\mathrm{U}$ \\
\hline $\begin{array}{l}\text { interleukin } 6 \text { receptor, IL6R } \\
\text { (T97204) }\end{array}$ & 0 & 0.0971361 & 0.19596 & 0.020219 & 0 & 0.0151475 & 0.74477 & $\underline{-0.968225}$ & $\mathrm{X}$ & $\mathrm{D}$ \\
\hline $\begin{array}{l}\text { protein kinase, NYD-SP15 } \\
\text { (W01831) }\end{array}$ & 0 & -0.027191 & -0.195606 & 0.070939 & 0 & -0.414562 & 0.04623 & 0.1662574 & $X$ & $\mathrm{X}$ \\
\hline $\begin{array}{l}\text { sorting nexin } 18, \text { SNX18 } \\
\text { (W07163) }\end{array}$ & 0 & -0.022802 & 0.127543 & 0.688726 & 0 & $\underline{-1.162211}$ & $\underline{-2.26711}$ & -0.157089 & $\mathrm{X}$ & $\mathrm{D}$ \\
\hline $\begin{array}{l}\text { CAMPATH-1 antigen, CDW52 } \\
\text { (W16557) }\end{array}$ & 0 & -0.623269 & -0.078545 & -0.300141 & 0 & -0.195291 & $\underline{1.19173}$ & 0.8875162 & $\mathrm{X}$ & $\mathrm{U}$ \\
\hline $\begin{array}{l}\text { Meis1 (mouse) homolog, MEIS1 } \\
\text { (W21073) }\end{array}$ & 0 & $\underline{-1.22706}$ & $\underline{-1.449073}$ & $\underline{-1.09416}$ & 0 & $\underline{-0.984974}$ & $\underline{1.16531}$ & -0.466385 & $\mathrm{D}$ & $\mathrm{C}$ \\
\hline $\begin{array}{l}\text { transcription factor } 3, \mathrm{TCF} 3 \\
\text { (W31285) }\end{array}$ & 0 & -1.011298 & -0.723657 & -1.420391 & 0 & -1.282373 & -0.68172 & -0.054073 & $\mathrm{D}$ & $\mathrm{D}$ \\
\hline $\begin{array}{l}\text { Muscleblind-like 2, MBNL2 } \\
\text { (W31757) }\end{array}$ & 0 & -0.245268 & -0.553002 & -0.848831 & 0 & -0.332846 & -0.24676 & 0.4830783 & $\mathrm{X}$ & $\mathrm{X}$ \\
\hline $\begin{array}{l}\text { protein kinase } \mathrm{C} \zeta, \text { PRKCZ } \\
\text { (W31814) }\end{array}$ & 0 & 0.1731776 & 0.128641 & 0.372295 & 0 & $\underline{1.2264064}$ & $\underline{1.7746}$ & $\underline{1.1494016}$ & $\mathrm{X}$ & $\mathrm{U}$ \\
\hline $\begin{array}{l}\text { hypothetical protein } \\
\text { DKFZP564K0822 (W45117) }\end{array}$ & 0 & -0.279088 & $\underline{-1.422535}$ & -0.006241 & 0 & -1.129144 & $\underline{1.17254}$ & -0.166658 & $\mathrm{D}$ & $\mathrm{C}$ \\
\hline endothelin 3, EDN3 (W60669) & 0 & $\underline{-1.679162}$ & $\underline{-1.02444}$ & $\underline{-1.298149}$ & 0 & $\underline{-2.07564}$ & 0.0671 & -0.155841 & $\mathrm{D}$ & $\mathrm{D}$ \\
\hline $\begin{array}{l}\text { carboxypeptidase B2, CPB2 } \\
\text { (W88434) }\end{array}$ & 0 & -1.351545 & -1.303844 & -0.8307 & 0 & -1.20625 & -0.94582 & -0.095514 & $\mathrm{D}$ & $\mathrm{D}$ \\
\hline unknown EST (W88435) & 0 & 0.5072158 & 0.612435 & -0.158399 & 0 & -1.761454 & -0.7512 & 0.6501167 & $X$ & $\mathrm{D}$ \\
\hline unknown EST (W90529) & 0 & -0.70369 & 0.014628 & 0.15159 & 0 & -0.480185 & 0.19725 & 0.5011758 & $\mathrm{X}$ & $\mathrm{X}$ \\
\hline
\end{tabular}

Values are normalized against unirradiated (nX) HCT116 CloneK_XRS or unirradiated (nX) HCT116 Clone__XRR. XK refers to irradiated HCT116 CloneK_XRS whereas X2 refers to irradiated HCT116 Clone2_XRR. Average values were obtained from either three or four independent experiments. M10, 10 min; H6, 6 h; H24, 24 h; X, not modulated; D, down-regulated; U, up-regulated; C, either down-regulation followed by up-regulation or vice versa. Values underlined are $-0.9<\log _{2}$ ratio or $\log _{2}$ ratio $>0.9$. 
Table II. Summary of genes that were differentially modulated from Table I.

\begin{tabular}{|c|c|c|c|c|c|c|c|c|c|c|}
\hline & \multicolumn{3}{|c|}{ CLK } & \multicolumn{3}{|c|}{ CL2 } & \multirow{2}{*}{$\frac{\text { Non-CLK+CL2 }}{\mathrm{X}-\mathrm{X}}$} & \multicolumn{3}{|c|}{$\mathrm{CLK}+\mathrm{CL} 2$} \\
\hline & $\mathrm{D}-\mathrm{X}$ & U-X & $C-X$ & X-D & $\mathrm{X}-\mathrm{U}$ & $\mathrm{X}-\mathrm{C}$ & & C-D/D-C & U-D/D-U & D-D/U-U \\
\hline & 21 & 12 & 0 & 23 & 28 & 2 & & 3 & 10 & 6 \\
\hline & $64 \%$ & $36 \%$ & $0 \%$ & $43 \%$ & $53 \%$ & $4 \%$ & & $16 \%$ & $53 \%$ & $31 \%$ \\
\hline \multirow[t]{2}{*}{ Sum } & & 33 & & & 53 & & 15 & & 19 & \\
\hline & & $28 \%$ & & & $44 \%$ & & $12 \%$ & & $16 \%$ & \\
\hline
\end{tabular}

Total number of regulated genes in CLK is $33+19=52$ whereas that for CL2 is $53+19=72$. Non-CLK+CL2 or CLK+CL2: not regulated or regulated in both cell clones. CLK, regulated only in HCT116 CloneK_XRS; CL2, regulated only in HCT116 Clone2_XRR; Non-, not regulated in both CLK and CL2; CLK+CL2, regulated in both CLK and CL2; D, down-regulated; U, up-regulated; C, either down-regulation followed by upregulation or vice versa; and $\mathrm{X}$, not regulated.

ncbi.nlm.nih.gov/geo/], under the following accession numbers: GSM7801-GSM7818, GSM7833, GSM7849-GSM7853, GSM12607-GSM12622, GPL350-GPL351, GPL353-GPL354, GPL567, GSE522-GSE526, and GSE797-GSE801.

Western blot analysis. Cells were lysed by sonication for $15 \mathrm{sec}$ at $4^{\circ} \mathrm{C}$ in RIPA buffer (1X PBS, $1 \%$ Nonidet P-40, $0.5 \%$ sodium deoxycholate, $0.1 \%$ SDS) containing protease inhibitors $(1.5 \mu \mathrm{g} / \mathrm{ml}$ chymotrypsin, $0.8 \mu \mathrm{g} / \mathrm{ml}$ thermolysin, $1.0 \mathrm{mg} / \mathrm{ml}$ papain, $1.5 \mu \mathrm{g} / \mathrm{ml}$ pronase, $1.5 \mu \mathrm{g} / \mathrm{ml}$ pancreatic extract, $0.002 \mu \mathrm{g} / \mathrm{ml}$ trypsin). The protease inhibitors were purchased from Roche Applied Science. Proteins present in the cell lysates were resolved by SDS-polyacrylamide gel electrophoresis using a $10 \%$ gel (100 $\mu \mathrm{g} /$ lane $)$ and electrotransferred to nitrocellulose membrane Hybond-C+ (Amersham Pharmacia Biotech, Piscataway, NJ, USA). Hybridization with mouse monoclonal anti-p53 antibody (Ab-6) (Invitrogen Canada Inc, ON), anti-HSP27, anti-HSP70, anti-HSP90 (Stressgen Biotech. Corp., BC), anti-Ku (Ab-4) (Lab Vision Corp., CA), anti-RAD51 (EMD Biosciences, Inc., CA), antiPARP (EMD Biosciences, Inc., CA), or anti-tubulin (EMD Biosciences, Inc., CA) was followed by immunodetection with ECL-Plus Western blot detection kit (Amersham Pharmacia Biotech).

\section{Results}

From the microarray analysis, we found that the logarithmic to base 2 (i.e. $\log _{2}$ ) of the intensity ratio between HCT116 Clone2_XRR or HCT116 CloneK_XRS and HCT116 Clone10_control for all 19200 genes/ESTs showed a logarithmic-normal distribution (data not shown). This provided us with the statistical basis to do paired t-test analysis. To facilitate comparison of the differences in gene expression, we further normalized our data by subtracting the mean value of the unirradiated control cells from the mean value at each time point (i.e. this gave the unirradiated control cells a mean value of zero for each gene as this group had been subtracted from itself). Table I shows the resulting normalized values of these genes/ESTs. Out of 19,200 genes/ESTs that were interrogated, we found only 120 that were differentially modulated/expressed in at least one of the four time points (i.e. either before or $10 \mathrm{~min}$,
$6 \mathrm{~h}$, or $24 \mathrm{~h}$ following XR treatment). The majority ( 83 genes or $69 \%$ ) of the 120 genes identified were unknown EST or hypothetical genes. Note, for these genes to be assessed as differentially modulated, they had to satisfy two criteria: a) $\mathrm{p}<0.05$ (by paired t-test), and b) at least two-third of the replicates at each time point had unnormalized values that were either $>2^{+0.9}$ (i.e., up-regulated) or $<2^{-0.9}$ (i.e., downregulated).

Table II shows an overall summary of the numbers of genes/ESTs that were identified as differentially modulated from Table I. Very few (19 genes or 16\%) were modulated at all time points in both HCT116 CloneK_XRS and HCT116 Clone2_XRR cells (Table II; denoted by no $\mathrm{X}$ in the last two columns of Table I). Similarly, very few (15 genes or $12 \%$ ) were not modulated at any time point in both HCT116CloneK_XRS and HCT116 ${ }^{\text {Clone2_XRR }}$ cells (Table II; denoted by an X in both of the last two columns of Table I). There were, however, 52 genes $(43 \%)$ that were modulated in HCT116 CloneK_XRS and 72 genes $(60 \%)$ that were modulated in HCT116 Clone2_XRR cells. Of the 52 genes from HCT116 CloneK_XRS cells, $73 \%$ were downregulated whereas there were almost equal numbers of downregulated versus up-regulated genes in HCT116 $16^{\text {Clone2_XRR }}$ (Table II). Thus our results have also identified relatively more down-regulated genes in the radiation-sensitive cells than in the radiation-resistant cells as a result of XR treatment.

Five genes demonstrated complex modulation (either down- followed by up-regulation, or vice versa) following XR treatment in HCT116 Clone2_XRR cells whereas there were no such complex modulated genes in HCT116 CloneK_XRS cells.

In general, fold changes of gene modulation were small, between 2- and 3-fold, with the exception of 7 genes that at certain time points were regulated $>4$-fold (Table I). These genes (with GenBank accession numbers) were SDC4

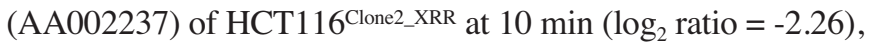
ALDH2 (AA012947) of HCT116 ${ }^{\text {CloneK_XRS }}$ at $10 \mathrm{~min}\left(\log _{2}\right.$ ratio $=-2.20)$, unknown EST (AA203190) of HCT116 CloneK_XRS at $10 \mathrm{~min}\left(\log _{2}\right.$ ratio $\left.=-2.24\right), \mathrm{ZNF} 35(\mathrm{H} 27140)$ of

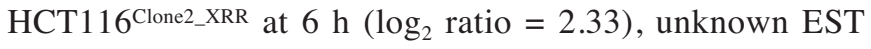
(T87942) of HCT116 Clone2_XRR at $10 \mathrm{~min}\left(\log _{2}\right.$ ratio $\left.=-2.14\right)$, SNX18 (W07163) of HCT116 Clone2_XRR at $6 \mathrm{~h}\left(\log _{2}\right.$ ratio $=$ -2.27), and EDN3 (W60669) of HCT116 Clone2_XRR at $10 \mathrm{~min}$ 


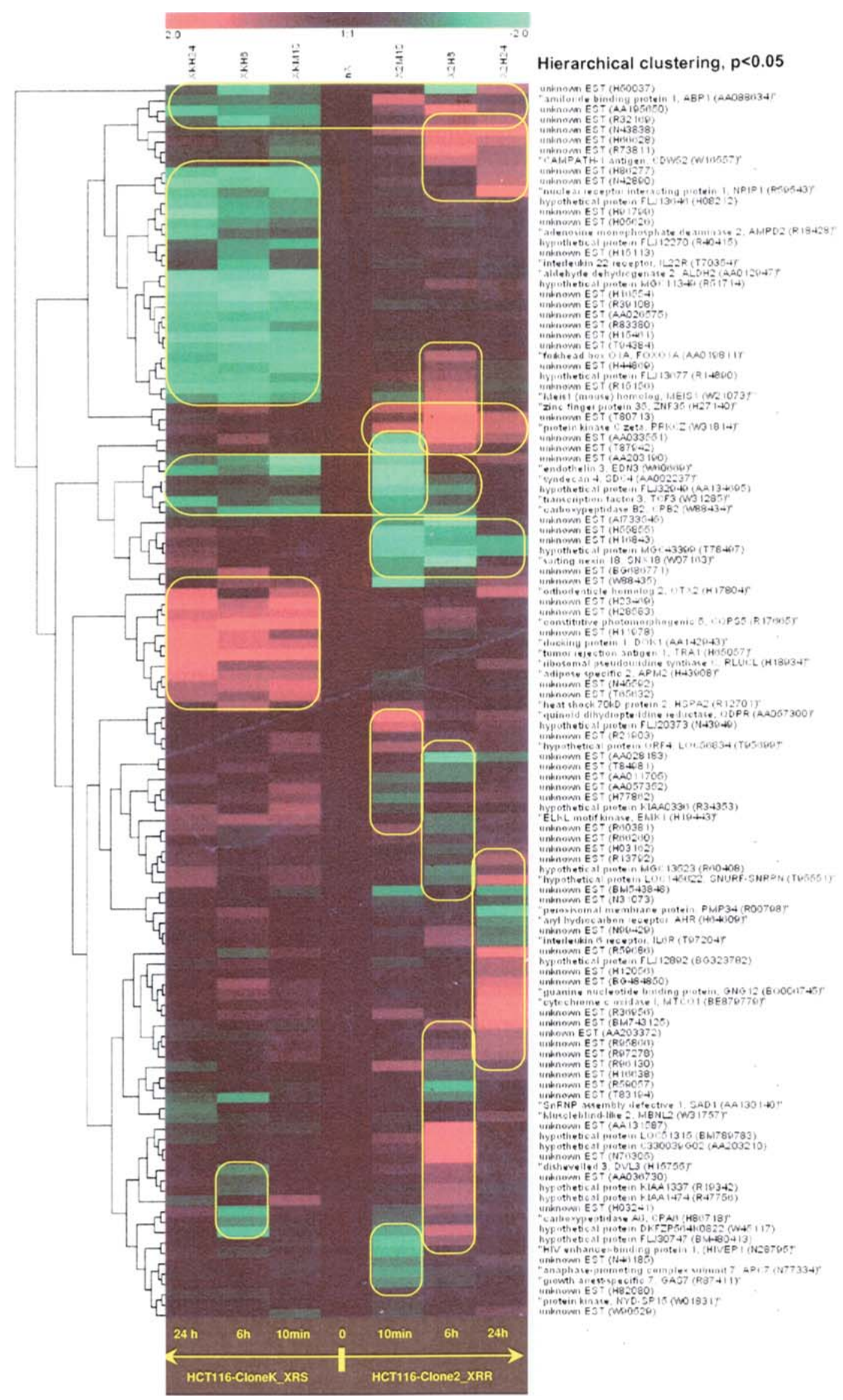

Figure 1. A hierarchical cluster analysis of 120 genes that were identified as differentially expressed (according to criteria described in the text) at one of the four time points after treatment with 4-Gy XR. The analysis followed a method described by Sturn et al (11). Normalized value of $\log _{2} \operatorname{ratio}$ is given (see text for explanation of how ratio is calculated). Colored bar scale is set from green to red representing down-regulation $\left(-2>\log _{2}\right.$ ratio) to up-regulation ( $\log _{2}$ ratio <+2). Genes marked with a yellow rectangle are those that clustered together to give an expression pattern over the time course or at certain time points in HCT116 $6^{\text {CloneK_XRS }}$ and/or HCT116 $6^{\text {Clone2_XRR }}$ cells. 


\section{A. HCT116 Clonek_XRS}

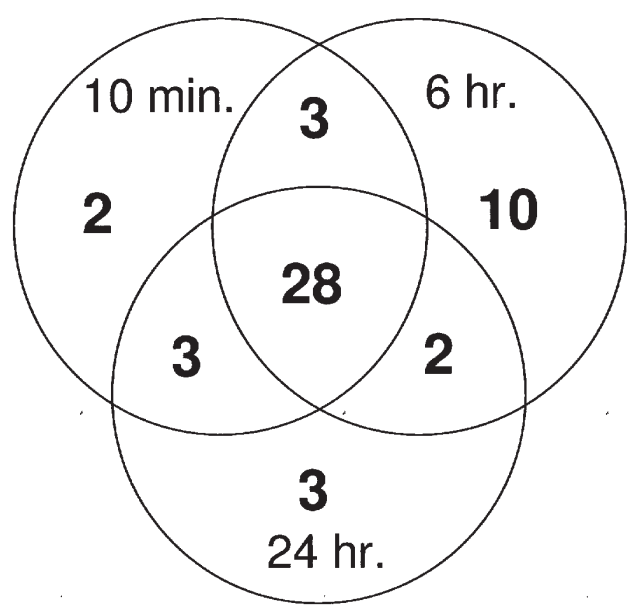

B. HCT116 Clone2_XRF

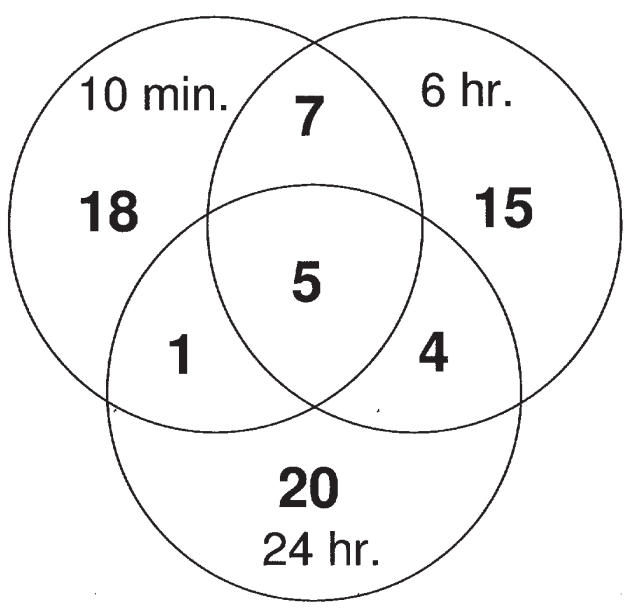

Figure 2. Venn diagram of number of genes expressed at either overlapping or individual time points in (A) HCT116 ${ }^{\text {CloneK_XRS }}$, and (B) HCT116 Clone2_XRR cells.

$\left(\log _{2}\right.$ ratio $\left.=-2.08\right)$. Note, ratio refers to the ratio of the intensity between HCT116 $6^{\text {Clone2_XRR }}$ or HCT116 $16^{\text {CloneK_XRS }}$ and HCT116 Clone10_control from the microarray analysis. Also, the negative sign in the $\log _{2}$ value refers to down-regulation whereas a positive sign refers to up-regulation relative to the control HCT116 Clone10_control.

Fig. 1 depicts the patterns of gene expression after 4-Gy XR treatment following hierarchical clustering analysis. It suggests that different patterns of gene modulation were observed in HCT116 $6^{\text {Clone2_XRR }}$ versus HCT116 ${ }^{\text {CloneK_XRS }}$ cells after XR. Further analysis of these results suggested that there were more clusters of genes being consistently up- or down-regulated up to $24 \mathrm{~h}$ post-irradiation in HCT116 CloneK_XRS than in HCT116 ${ }^{\text {Clone2_XRR }}$. In the latter cells, there was a more complex pattern of gene expression (i.e. relatively fewer genes that were consistently up- or down-regulated along the time course). The results also suggest that there was earlier modulation of a larger number of genes in the radiosensitive than in the radioresistant cells. Specifically, there were approximately twice as many genes that responded as early as 10 min after XR treatment in HCT116 CloneK_XRS cells (59\%) than in HCT116 ${ }^{\text {Clone2_XRR }}$ cells $(33 \%)$ (Fig. 2A and B). Also, there were more genes that, once modulated (e.g. as early as $10 \mathrm{~min}$ ), stayed modulated for the rest of the time course in the radiosensitive than in the radioresistant cells (Fig. 2A and $\mathrm{B}$ ).

Of 51 genes $(55 \%)$ of HCT $116^{\text {CloneK_XRS }}$ cells, 28 were differentially modulated at all time points (i.e., these genes responded as early as 10 min following XR treatment and did not undergo further changes in expression over the time course) (Fig. 2A). By contrast, only 5 out of 70 genes (7\%) were differentially modulated at all time points in

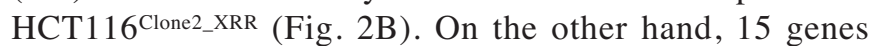
(29\%) were differentially modulated at only one of the time points in HCT116 $6^{\text {CloneK_XRs; }}$ the specific numbers were 2 genes at $10 \mathrm{~min}, 10$ genes at $6 \mathrm{~h}$, and 3 genes at $24 \mathrm{~h}$. For HCT116 Clone2_XRR, 53 genes $(76 \%)$ were differentially modulated at one of the time points and the corresponding numbers were 18 genes at $10 \mathrm{~min}, 15$ genes at $6 \mathrm{~h}$, and 20 genes at $24 \mathrm{~h}$.
Thus our results suggest that the radiosensitive phenotype may be associated with more consistent patterns of early gene expression than the radioresistant phenotype which may be associated with the continued expression of different genes along the time course.

A generally similar pattern was observed with real-time PCR (RT-PCR) of selected ESTs and known genes of both clones, HCT116 $6^{\text {CloneK_XRS }}$ and HCT116 $6^{\text {Clone2_XRR }}$. Out of 14 genes and unknown ESTs tested in a time course of both clones following 4-Gy XR, four were affected at all time points. They were unknown EST (H86277) in HCT116 Clone2_XRR, unknown EST (N42890) in HCT116 CloneK_XRS, APM2 in both HCT1 16 $6^{\text {CloneK_Xrs }}$ and HCT116 $16^{\text {Clone2_XRR }}$, and BRCA1 in HCT116 ${ }^{\text {Clone2_XRR }}$ cells. Five (in HCT116 ${ }^{\text {CloneK_XRS }}$ ) or six (in HCT116 Clone2_XRR) genes and unknown ESTs (35.7\% or $42.9 \%$, respectively) responded as early as $10 \mathrm{~min}$ after XR treatment in HCT116 CloneK_XRS or HCT116 ${ }^{\text {Clone2_XRR }}$ cells. In addition, the fold changes by RT-PCR of differentially expressed genes after XR were also generally not large (i.e. $<3$ - or 4-fold) except in the case of APM2. Therefore, our RT-PCR data agreed with the cDNA microarray in suggesting that only relatively small changes of gene expression had taken place up to $24 \mathrm{~h}$ following XR treatment.

Our results suggest that the majority of genes important for DNA damage sensor/repair, cell cycle, and apoptosis were not modulated up to $24 \mathrm{~h}$ after XR treatment at $4 \mathrm{~Gy}$. In fact, most of the genes listed in Table I, except for FOXO1A (AA019811), APC7 (N77334), HSPA2 (R12701), and GAS7 (R87411), are not known to be involved in DNA damage sensor/repair, cell cycle, and apoptosis. Out of 79 genes (from the 19200 that were interrogated) usually categorized as DNA damage sensor/repair and cell cycle related genes, none were modulated in HCT116 $6^{\text {CloneK_XRS }}$ cells. By contrast, 10 of these 79 genes $(12.7 \%)$ were modulated in HCT116 Clone2_XRR cells up to $24 \mathrm{~h}$ after XR treatment. These 10 genes and their $\log _{2}$ ratios are shown in Table III.

Furthermore, out of 76 genes (from 19200 examined) that are categorized as apoptosis related genes, only $2(2.6 \%)$ and $7(9.2 \%)$ were regulated in HCT $116^{\text {CloneK_XRS }}$ and 
Table III. Representative genes from 79 DNA damage sensor/repair and cell cycle, 76 apoptosis, and 40 housekeeping related genes that were either down- or up-regulated in HCT116 CloneK_XRS or HCT116 Clone2_XRR cells.

\begin{tabular}{|c|c|c|c|c|c|c|c|c|c|c|}
\hline Gene (acc. no.) & $\mathrm{nX}$ & XKM10 & XKH6 & XKH24 & $\mathrm{nX}$ & $\mathrm{X} 2 \mathrm{M} 10$ & $\mathrm{X} 2 \mathrm{H} 6$ & $\mathrm{X} 2 \mathrm{H} 24$ & CLK & CL2 \\
\hline $\begin{array}{l}\text { NA damage sensor/repair and cell cycle: } \\
\text { cyclin G associated kinase, } \\
\text { GAK (H18275) }\end{array}$ & 0 & -0.056698 & -0.20082 & -0.27877 & 0 & $\underline{-0.941175}$ & 1.0870326 & -0.01268 & $\mathrm{X}$ & $\mathrm{C}$ \\
\hline $\begin{array}{l}\text { cyclin D-type binding-protein 1, } \\
\text { CCNDBP1 (H53894) }\end{array}$ & 0 & -0.689562 & -0.70741 & -0.30699 & 0 & 0.273176 & 0.3418403 & $\underline{1.002506}$ & $\mathrm{X}$ & $\mathrm{U}$ \\
\hline $\begin{array}{l}\text { cell division cycle } 6 \text { homolog, } \\
\text { CDC6 (H59203) }\end{array}$ & 0 & -0.076016 & -0.09243 & -0.24169 & 0 & 0.489718 & $\underline{1.2362879}$ & $\underline{0.942679}$ & $\mathrm{X}$ & $\mathrm{U}$ \\
\hline cyclin D3, CCND3 (H89623) & 0 & 0.1602291 & 0.021323 & -0.00631 & 0 & 0.018732 & 0.4879046 & $\underline{0.981933}$ & $\mathrm{X}$ & $\mathrm{U}$ \\
\hline $\begin{array}{l}\text { Rad50-interacting protein 1, } \\
\text { RAD50IP (N44277) }\end{array}$ & 0 & 0.1080305 & -0.46295 & 0.049636 & 0 & 0.867852 & $\underline{0.9779612}$ & 0.489618 & $\mathrm{X}$ & $\mathrm{U}$ \\
\hline $\begin{array}{l}\text { cyclin-dependent kinase inhibitor 1B/ } \\
\text { p27/Kip1, CDKN1B (N47660) }\end{array}$ & 0 & -0.648855 & -0.3007 & -0.5167 & 0 & 0.013597 & $\underline{1.2212343}$ & -0.26689 & $\mathrm{X}$ & $\mathrm{U}$ \\
\hline $\begin{array}{l}\text { cyclin-dependent kinase inhibitor 2C/ } \\
\text { p18, CDKN2C (W00390) }\end{array}$ & 0 & 0.1251529 & -0.00567 & -0.12853 & 0 & 0.121644 & -0.699528 & $\underline{-1.08442}$ & $\mathrm{X}$ & $\mathrm{D}$ \\
\hline RAD1 (AA029857) & 0 & 0.8932292 & 0.09586 & 0.361204 & 0 & 0.127905 & $\underline{1.2304863}$ & 0.551378 & $\mathrm{X}$ & $\mathrm{U}$ \\
\hline $\begin{array}{l}\text { Excis repair cross-compl repair } \\
\text { defi 5, ERCC5 (AA028978) }\end{array}$ & 0 & 0.2639138 & 0.474919 & 0.774904 & 0 & -0.028159 & $\underline{1.0036795}$ & 0.099429 & $\mathrm{X}$ & $\mathrm{U}$ \\
\hline cyclin C, CCNC (AA044196) & 0 & -0.151892 & -0.1759 & 0.63771 & 0 & $\underline{-0.942359}$ & -0.037333 & -0.6675 & $\mathrm{X}$ & $\mathrm{D}$ \\
\hline \multicolumn{11}{|l|}{ Apoptosis } \\
\hline $\begin{array}{l}\text { CASP2-RIPK1 containing death } \\
\text { domain,CRADD (T78285) }\end{array}$ & 0 & 0.81989 & $\underline{1.09599}$ & 0.8906334 & 0 & 0.0506 & -0.1358 & -0.213 & $\mathrm{U}$ & $X$ \\
\hline $\begin{array}{l}\text { programmed cell death } 6 \text { IP, } \\
\text { PDCD61P (R94810) }\end{array}$ & 0 & -1.2282 & -0.14179 & -0.427605 & 0 & -0.3924 & 0.3815 & -0.047 & $\mathrm{D}$ & $X$ \\
\hline $\begin{array}{l}\text { DEAD/H box polypeptide 16, } \\
\text { DDX16 (T93721) }\end{array}$ & 0 & -0.37282 & -0.56059 & -0.610502 & 0 & -1.3182 & $\underline{1.3202}$ & 0.8009 & $X$ & $\mathrm{C}$ \\
\hline $\begin{array}{l}\text { BCL2-associated athanogene 1, } \\
\text { BAG1 (T97408) }\end{array}$ & 0 & 0.86486 & 0.21315 & -0.043856 & 0 & 0.0779 & $\underline{1.1621}$ & -0.354 & $X$ & $\mathrm{U}$ \\
\hline $\begin{array}{l}\text { DEAD/H box polypeptide 3, } \\
\text { DDX3 (R34214) }\end{array}$ & 0 & -0.23195 & -0.05218 & -0.001952 & 0 & -0.5424 & -1.5375 & -0.295 & $\mathrm{X}$ & $\mathrm{D}$ \\
\hline $\begin{array}{l}\text { Fas (TNFRSF6) associated factor 1, } \\
\text { FAF1 (R70834) }\end{array}$ & 0 & 0.39996 & 0.08053 & -0.07148 & 0 & -0.8599 & $\underline{-1.1621}$ & -0.615 & $X$ & $\mathrm{D}$ \\
\hline $\begin{array}{l}\text { regulator of Fas-induced apoptosis, } \\
\text { TOSO (BG753958) }\end{array}$ & 0 & 0.08724 & 0.11909 & 0.1660024 & 0 & -0.4658 & $\underline{0.9236}$ & 0.1059 & $X$ & $\mathrm{U}$ \\
\hline $\begin{array}{l}\text { Bcl-2 modifying factor, BMF } \\
\text { (AA044013) }\end{array}$ & 0 & -0.26609 & -0.50033 & -0.185527 & 0 & -0.0591 & 1.0231 & 0.1503 & $X$ & $\mathrm{U}$ \\
\hline $\begin{array}{l}\text { BCL2-associated athanogene 3, } \\
\text { BAG3 (BM800951) }\end{array}$ & 0 & 0.11924 & 0.05474 & 0.0696484 & 0 & -0.2306 & $\underline{1.8615}$ & -0.059 & $X$ & $\mathrm{U}$ \\
\hline $\begin{array}{l}\text { House-keeping } \\
\text { ribosomal protein S6 kinase, } \\
\text { RPS6KA5 (R11183) }\end{array}$ & 0 & -0.627262 & $\underline{-0.9104199}$ & $\underline{-1.006457}$ & 0 & 0.351658 & 0.58076 & 0.022889 & $\mathrm{D}$ & $X$ \\
\hline B-2-microglobulin, B2M (R23341) & 0 & $\underline{0.932468}$ & 0.2566367 & 0.4750074 & 0 & 0.175949 & -0.3118 & -0.11517 & $\mathrm{U}$ & $\mathrm{X}$ \\
\hline $\begin{array}{l}\text { transferrin receptor 2, } \\
\text { TFR2 (R35943) }\end{array}$ & 0 & 0.812215 & 0.3238287 & 0.2938239 & 0 & -0.20656 & -0.7711 & $\underline{-1.05867}$ & $\mathrm{X}$ & $\mathrm{D}$ \\
\hline $\begin{array}{l}\text { ribosomal protein L24, PRL24 } \\
\text { (H18707) }\end{array}$ & 0 & 0.051493 & 0.1885772 & 0.5814908 & 0 & $\underline{-0.95326}$ & 0.00888 & -0.33902 & $\mathrm{X}$ & $\mathrm{D}$ \\
\hline ß-tubulin, TUBB4 (H27908) & 0 & 0.271675 & 0.4117983 & 0.3126816 & 0 & -0.40428 & -0.1951 & -1.05867 & $\mathrm{X}$ & $\mathrm{D}$ \\
\hline $\begin{array}{l}\text { ribosomal protein S19, RPS } 19 \\
\text { (AA046433) }\end{array}$ & 0 & 0.295753 & 0.1291897 & 0.1941708 & 0 & 0.290458 & $\underline{1.16745}$ & 0.301401 & $\mathrm{X}$ & $\mathrm{U}$ \\
\hline
\end{tabular}




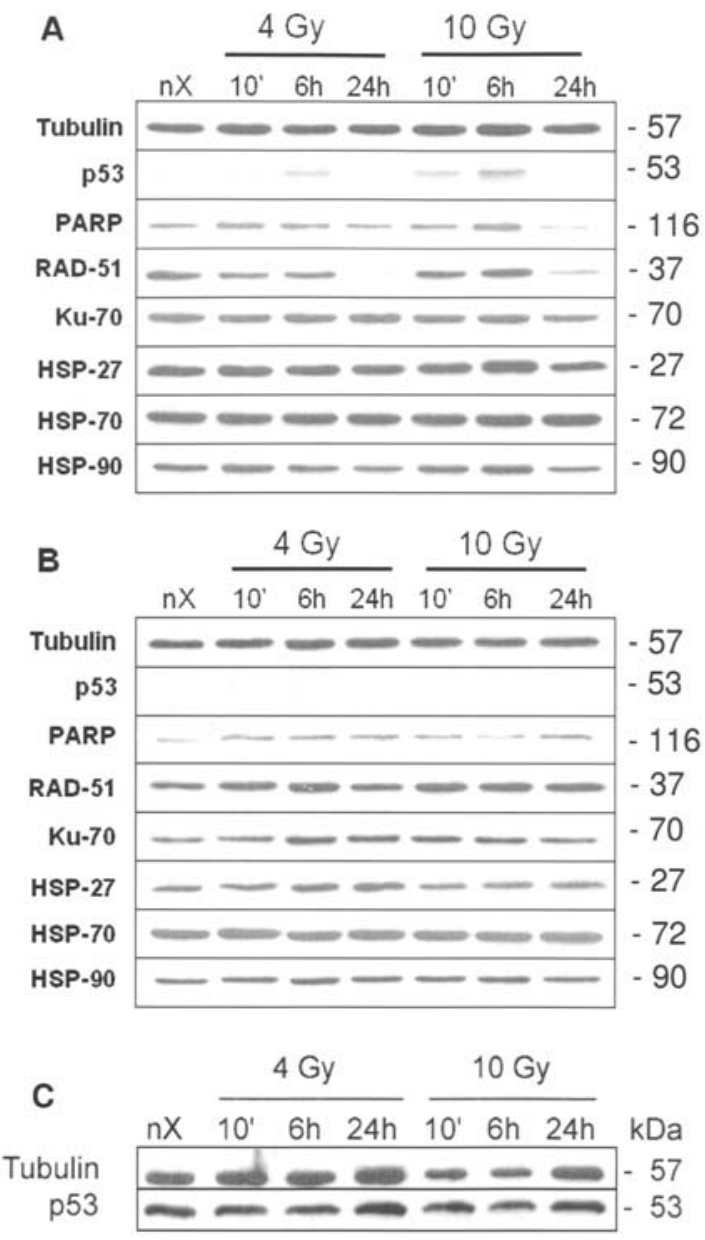

Figure 3. Western blot analysis of total proteins from (A) HCT116 $6^{\mathrm{TP} 53+/+}$ cells, (B) HCT116 $6^{\mathrm{TP} 53-/-}$ cells, or (C) COS-7 cells before, or $10 \mathrm{~min}, 6 \mathrm{~h}$, or $24 \mathrm{~h}$ following XR treatment at either 4 or $10 \mathrm{~Gy}$. The latter two cell lines (HCT116 $16^{\mathrm{TP} 53-/}$, COS-7) were added as further controls to compare with HCT $116^{\mathrm{TP} 53+/+}$ cells.

HCT116 Clone2_XRR cells, respectively, up to 24 hours after XR treatment (Table III). There were no common genes that were modulated in both radiosensitive and radioresistant cells.

As additional control, we also evaluated 40 housekeeping genes from our cDNA microarray data. Of these $2(5 \%)$ and 4 (10\%) were regulated in HCT116 $6^{\text {CloneK_XRS }}$ and HCT116 $6^{\text {Clone2_XRR }}$ cells, respectively, up to $24 \mathrm{~h}$ after XR treatment (Table III). There were no common genes that were regulated in both radiosensitive and radioresistant cells.

\section{Discussion}

We expected to detect differential modulation of known pathways of DNA damage sensor/repair, cell cycle, or apoptosis after XR treatment between our radiation-resistant and -sensitive cells that could possibly account for their radiation response phenotypes. This was because these radiationresistant or -sensitive clones were closely related genetically but differed only in their XR-resistance or -sensitivity (9). However, our cDNA microarray results have demonstrated that at least up to $24 \mathrm{~h}$ after XR treatment with an acute dose of $4 \mathrm{~Gy}$, which would have killed more than $50 \%$ of the cells in all the 3 clones used in our studies (9), there was no significant up-regulation or down-regulation of the majority of known DNA damage sensor/repair, cell cycle, and or apoptosis related genes in either clone when each was individually compared to the control clone with the same radiation response as the parental HCT116 cells. Instead, our results suggested potentially novel genes, or even new pathways, that may or may not interact with the known DNA damage response routes (detection, repair, cell cycle, apoptosis) that can putatively lead to sensitivity or resistance to XR (1).

Several studies have attempted to address the genetic basis of radiation response, either in cell lines or tumor biopsies, using cDNA microarray as high throughput screening $(4-8,12)$. These studies have provided candidates of radiation-responsive molecules. One such example, as reported by Guo et al (4), was MnSOD, which was associated with mediating cellular radioresistance. Although we did not observe any modulation of SOD1 (N28535) in our DNA chips, their data agreed with ours, from the point of view that both our studies did not identify known DNA damage sensor/repair, cell cycle, and/ or apoptosis related genes as being significantly regulated following XR. With respect to DNA double-strand breaks that were produced by X-radiation, none of the genes involved in non-homologous end joining repair mechanism, i.e. ATM, Ku70, Ku80, XRCC4, DNA Ligase IV, and DNA-PKcs, were significantly modulated. In fact, when Leong et al (13) analyzed lymphoblastoid cell samples from 36 radiationsensitive individuals according to well-defined radiation response grading (RTOG grades 3 and 4), none of those proteins were abnormal, suggesting that their genetic expression was not changed following XR treatment. Again, this clinical report supports our cDNA microarray data in that radiation response within $24 \mathrm{~h}$ after XR treatment may involve different sets of genes responding before the known DNA damage sensor/repair, cell cycle, and or apoptosis related genes.

Because it is well known that effector molecules involved in DNA damage response (e.g. repair, apoptosis) are involved at the late stages following radiation treatment, our results suggest that genome-wide screening with cDNA microarray especially at early time points $(<24 \mathrm{~h})$ post-irradiation is not suitable for assessing the differential expression of these molecule(s). We have evidence that at least one of the known effector molecules of DNA damage was functional in our studies. Specifically, we found a post-translational translocation of cytoplasmic TP53 into the nucleus (data not shown), regardless of the XR response status of our cells (all our clones have wt TP53 status). The TP53 protein level peaked at $6 \mathrm{~h}$ after XR treatment at either $4 \mathrm{~Gy}$ or $10 \mathrm{~Gy}$ (Fig. 3), and complete translocation was achieved within $24 \mathrm{~h}$ following the treatment with the higher dose. We also have evidence that probably as a consequence of the post-translational XR response of TP53, known molecules that are important for DNA damage sensor/repair or apoptosis such as PARP and RAD-51 were also modulated (Fig. 3), and that the latter seemed to be dependent on the presence of TP53 $(14,15)$.

Our results show that $4-\mathrm{Gy} \mathrm{XR}$, in the early period $(<24 \mathrm{~h})$ after irradiation, acts mostly to suppress genetic expression rather than inducing it in the radiosensitive phenotype of 
HCT116 $6^{\text {CloneK_XRS }}$ cells. The significance of this observation is presently unknown. Our results also suggest that our radiosensitive cells show earlier modulation of a larger number of genes compared to the radioresistant phenotype. Whether the number of genes responding early to XR treatment is in fact correlated with the radiation response of these or other types of cells warrants further studies.

By contrast, many more different genes responded at different time points after XR in the resistant cells relative to the sensitive cells. This suggests that radioresistance of HCT116 ${ }^{\text {Clone2_XRR }}$ cells was gained through continued activation of different genes over the time course. Thus these genes could possibly be used as XR response marker at certain time points following the treatment. Additionally, since the fold changes of differentially expressed genes after XR were not large, our results suggest that only small fold changes (2- to 4-fold) were needed to activate an XR-response that led to subsequent radiosensitivity or radioresistance in our model.

Finally, because XR treatments are usually delivered clinically as fractionated daily doses of $2 \mathrm{~Gy}$, it is possible that our present results (with a single dose of 4 Gy) may reflect the very early cellular response to radiotherapy. Our findings further strengthen the possibility of clinical radiosensitivity being a complex trait, possibly involving novel or new pathways in addition to the well-documented pathways (1).

In conclusion, the radiation response of our model system (HCT116 clones) up to $24 \mathrm{~h}$ following XR does not involve substantial mobilization of known DNA damage response pathways. Instead, it appears to involve novel or unestablished cellular response pathways. Our findings might further support clinical radiosensitivity or radioresistance as a complex trait.

\section{Acknowledgments}

This study was supported by a grant to C.E. Ng from the National Cancer Institute of Canada with funds from the Canadian Cancer Society.

\section{References}

1. Andreassen CN, Alsner J and Overgaard J: Does variability in normal tissue reactions after radiotherapy have a genetic basis where and how to look for it? Radiother Oncol 64: 131-140, 2002.

2. Khanna KK and Jackson SP: DNA double-strand breaks: signaling, repair and the cancer connection. Nat Genet 27: 247-254, 2001.

3. Zhivotovsky B, Joseph B and Orrenius S: Tumor radiosensitivity and apoptosis. Exp Cell Res 248: 10-17, 1999.

4. Guo G, Yan-Sanders Y, Lyn-Cook BD, et al: Manganese superoxide dismutase-mediated gene expression in radiationinduced adaptive responses. Mol Cell Biol 23: 2362-2378, 2003.

5. Hartmann KA, Modlich O, Prisack HB, Gerlach B and Bojar H: Gene expression profiling of advanced head and neck squamous cell carcinomas and two squamous cell carcinoma cell lines under radio/chemotherapy using cDNA arrays. Radiother Oncol 63: 309-320, 2002.

6. Kitahara O, Katagiri T, Tsunoda T, Harima Y and Nakamura Y: Classification of sensitivity or resistance of cervical cancers to ionizing radiation according to expression profiles of 62 genes selected by cDNA microarray analysis. Neoplasia 4: 295-303, 2002.

7. Li Z, Xia L, Lee LM, et al: Effector genes altered in MCF-7 human breast cancer cells after exposure to fractionated ionizing radiation. Radiat Res 155: 543-553, 2001.

8. Park WY, Hwang CI, Im CN, et al: Identification of radiationspecific responses from gene expression profile. Oncogene 21: 8521-8528, 2002

9. Qutob SS, Multani AS, Pathak S, Feng Y, Kendal WS and Ng CE: Comparison of the X-radiation, drug and ultraviolet-radiation responses of clones isolated from a human colorectal tumor cell line. Radiat Res 161: 326-334, 2004.

10. Brazma A, Hingamp P, Quackenbush J, et al: Minimum information about a microarray experiment (MIAME)-toward standards for microarray data. Nat Genet 29: 365-371, 2001.

11. Sturn A, Quackenbush J and Trajanoski Z: Genesis: cluster analysis of microarray data. Bioinformatics 18: 207-208, 2002.

12. Desnoyers S, Kaufmann SH and Poirier GG: Alteration of the nucleolar localization of poly(ADP-ribose) polymerase upon treatment with transcription inhibitors. Exp Cell Res 227: 146-153, 1996.

13. Leong T, Chao M, Bassal S and McKay M: Radiationhypersensitive cancer patients do not manifest protein expression abnormalities in components of the nonhomologous end-joining (NHEJ) pathway. Br J Cancer 88: 1251-1255, 2003.

14. Daboussi F, Dumay A, Delacote F and Lopez BS: DNA double-strand break repair signalling: the case of RAD51 posttranslational regulation. Cell Signal 14: 969-975, 2002.

15. Marcou Y, D'Andrea A, Jeggo PA and Plowman PN: Normal cellular radiosensitivity in an adult Fanconi anaemia patient with marked clinical radiosensitivity. Radiother Oncol 60: 75-79, 2001. 